\title{
英国の新たな交通計画体系構築に向けた試みとその我が国への示唆*
}

\section{Recent Transport Planning System in England and Its Lessons to Japan*}

加藤 浩徳 $* *$, 村木 美貴 $* * *$, 高橋 清 $* * * *$ By Hironori KATO**, Miki MURAKI*** and Kiyoshi TAKAHASHI****

\section{1. はじめに}

交通基盤は, 国土計画の中における極めて重要な一要素 である. 今後我が国が目指していくべきと考えられる,「少子 高齢社会における活力に溢れ個性的な地域社会の形成」, 「グローバル化の中での我が国の競争力·魅力の向上」, 「安全·安心な国土の形成」等を目指寸上でも, 人と人との交 流や物資の流動は不可欠であり, 交通基盤がその基礎であ ることには間違いない.

実際, 我が国においては,これまでの全国総合開発計画 や地域ブロック圈計画などにおいて, 交通施設の整備は計 画の重要な位置を占めてきた. だが, バブル経済崩壊後の 長期的な経済低迷を受けて, 国・地方公共団体の財政状況 の悪化，環境保全に対する社会的要請の高まり，地方分権 推進の流れの中で, 国の担うべき交通基盤整備あるい忙 の計画のあり方が改めて問われるようになりつつある.

本研究では, その問いに対する欧米における試みとして, 英国の交通計画システムの変革に焦点をあてることにした い. ただし，英国には我が国でイメージするような国土計画 はない. たかだか広域ブロック(region)の計画が最上位計 画である. また, 我が国以上に, 交通政策ならびに計画シス テムの変化のスピードが速い. そして英国内でも計画システ ムに対する見解は定まっておらず, 議論百出の状態である. したがって, 英国の経験は, 必ずしも我が国の計画システム の設計にすぐさま役立つものではないのかもしれない.しか し, 地理的環境条件, 地方自治体の仕組みや数, 中央集権 的な行政システム, 地方分権の世論の盛り上がり, 幹線交通 ネットワークの熟成度等, 部分的には共通する要素も見いだ されないわけではない. したがって, 英国の事例は, 我が国 の計画システムのあり方を議論する上でも有用な教訓が含 まれていると信じる次第である.

なお,ここでいら英国とは，いわゆるイングランドに限定す ることを明確にしておきたい. いわゆるイギリス(グレート・ブ リテンおよび北アイルランド連合王国)には, ウェールズ, ス

*キーワード:国土計画, 交通計画, 地域計画

** 正員, 博(工), 東京大学大学院工学系研究科講師

（東京都文京区本郷 7-3-1,

TEL:03-5841-7451,e-mail:kato@trip.t.u-tokyo.ac.j) **非会員, 博(工), 千葉大学工学部都市環境システム学科助教授 **正員, 工博, 北見工業大学工学部土木開発工学科助教授
コットランド, 北アイルランドも含まれるが, これらは英国(イ ングランド)とは別の社会的背景と計画システムを持っており, 本研究で取り扱引内容とは異なる。

また, 本研究で取り扱う交通は, 主に道路, 鉄道, バス及 びその他の地方交通(徒歩や二輪車)である. 一般に, 交通 には, 航空(空港を含む), 海運(港湾を含む), 内陸水運 (河川整備を含む)等も含まれるが，今回は紙面の都合上対 象としない. なお, いずれも本稿執筆時点(2002 年)の情報 であることを断っておく.

\section{2. ブレア政権登場までの英国における交通}

\section{（1英国の交通鬲要動向}

英国の交通需要は基本的に一貫して増加する傾向にあ る. 図-1 は, 1958 年以降のイギリスの旅客交通需要(人キ 口)を表したものである ${ }^{1)}$.これより, 総交通需要は過去 40 年 間で約 2.8 倍に増加していることがわかる. 交通機関別にそ の内訳をみると, 自動車需要が約 5.5 倍に増加しており, 1997 年では全交通需要の約 85\%を占めている. 一方で, バ ス需要は一貫して減少しており, 過去 40 年間で約半分にな っている. 鉄道需要はほぼ横ばいである. ちなみに, 我が

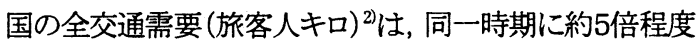
増加したり, そのうち自動車は約 13 倍に増加している.イ ギリスでは, 我が国よりは約10年早く, かつやや緩やかにモ 一タリゼーションが谁行した言える. なお, 図-1 より, 英国 では 1990 年に一度ピークがあった後, 一時, 需要の伸びが 下落し, 再度需要が増加している. 同時期の貨物交通需要 (トンキロ)の下落幅はさらに大きい.これは, 90 年からの数 年間, 英国の経済状況が悪化(GDP 減少)したことが大きく 影響している. なお 95 年以降の英国経済は活況を呈してお

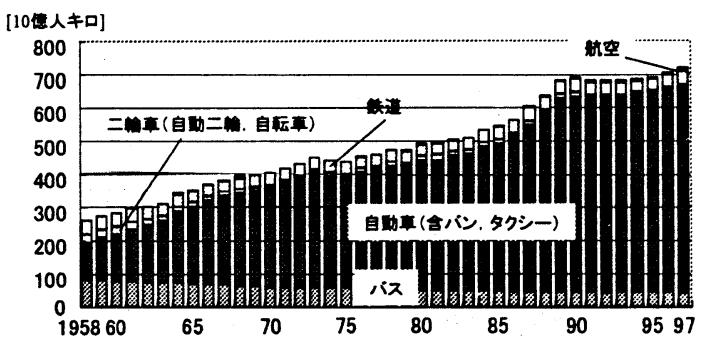

図-1 1958 97 年のイギリス(イングランド以外も含む) の旅客交通墨要の推移 
り, 交通需要は順調に増加ている.

今後の交通需要の見通しについては, 2000 年時点の中 央政府の予測 ${ }^{3}$ によると, 2010 年までの 10 年間で, 自動車 の台キロが $22 \%$ 増加することが見込まれている.これは, 我 が国で同期間に自動車需要が約 8\%増加することが予測され ている結果 と比較すると相当な伸びである.この違いは, 予測時点における将来GDPの想定が両国間で大きく異なる ことに起因すると考えられる.

このような交通需要の増加(あるいはその予想)に伴う道 路混雑とそれによる環境破壊, ならびに政府に対する交通 政策全体に対する英国民の批判は相当に強い. 2002 年春 に英国で実施された 1725 人を対象としたアンケート調査

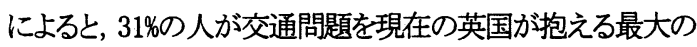
問題として取り上げており, そのうち最も多い課題を「交通混 雑」(19\%)としている.ちなみに, 英国は公共交通のサービス 水準が低いことがよく話題にされているが，これを交通の中 の最大課題と挙げているのは 8\%にすぎない. 少なくともこの 結果を見る限り, 交通混雑が相当に深刻な社会問題と認識 されていることが伺える.

\section{(2)ブレア労得党政権以前の英国の交通政策 ${ }^{6)}$}

英国では, 第二次世界大戦後間もない頃からモータリゼ ーションに対する警告が鳴らされてきた. 既にモータリゼー ションを経験していた米国の経験をもとに, 1963 年のブキャ ナンレポート》は, 自動車の普及によって交通環境が劇的に 変化し, 環境亡生活様式が深刻な影響を受けると予告した. 実際, 道路交通需要は先に見たようにかなり速い速度で増 加した. 1970 年代には, 環境保護の世論が強くなり, 道路整 備に対する風当たりがかなり強くなった時期もあった(この結 果として, 土地補償法の制定, 1973 年騒暗方止規則の制定, 道路法の改正等により, 道路計画の手続きに住民の関与が 積極的に組み込まれるようになった)が, 1980 年代は, サッ チャ一政権下であったこともあり, 経済開発の名目の元, 堅 実に道路整備が進められた. サッチャ一時代の 10 年間で, $18,400 \mathrm{~km}$ の道路が整備され，高速道路整備投資額は実質 で 60\%増加た. ところが, 1990 年代に入ると, 状況が一変 する. 中央政府の将来交通需要予測結果が発表されると, 従来の需要追随型の道路整備では, 増加し続ける交通需要 をカバーすることが困難のみならず, さらなる需要を生み出 す可能性が強いとの議論がなされるようになった. また, こ れに呼応して, 1994 年には中央政府より, 交通計画に関す る計画政策方針ガイダンス(Planning and Policy Guidance 13: PPG13)が発表され，自動車保有率の増加と交通混雑の深 刻化がもたらした中心市街地空洞化や環境負荷増大を防ぐ ことが, 各種開発を行う上で重要な視点とされた. 我が国の ケースから類推するに, 1990 年代前半の英国経済停滞が, 道路整備への批判を増強させたとも考えられる. いずれに せよ,こうした道路整備への逆風の中, ついにメージャ一保
守党政権は, 1994 年の幹線道路レビューの中で, 45 力所の 道路整備計画の完全撤回と, 他の計画の延期などを発表し た. 事実, 道路整備予算(名目ベース)は, 94 年度とそれ以 降数年間(例えば, 97 年度)を比較すると約 $35 \%$ も削減され ている.これは, 英国内でも道路政策の根本的な転換と受 け止められ話題となった. だが, 前保守党政権はこの転換を, 明確な政策変更として国民にアピールすることができなかっ た. 結局, この新たな交通政策の考えは, 現在の労働党政 権に受け継がれ, 計画システムの変革が害行されていくと となった.

一方で, 地方の交通政策に目を転じると, 先のブキャナン レポートが発表された後, 1968 年には, 都市農村計画法 (Town and Country Act)が改正され, デベロップメントプラン (Development Plan: DP)の中に交通計画を組み込むことが正 式に定められた.これにより, 交通需要を発生させる主要施 設を結節点周辺に配置する等, 交通計画と土地利用計画と の連携が可能となった. だが, DP は交通投資の予算とは必 ずしも直接連動しておらず,一方で中央政府はアドホックに 地方の交通プロジェクトに対して補助を行っていたため, 非 効率な投資が行われているとの批判を受けることとなった. これに対し, 1974 年に交通政策プログラム(Transport Policies and Programme: TPP)が創設され, 毎年, 地方自治 体は自らの考える優先順位に応じて，交通投資のための予 算を中央政府に申請(入札を通じた競争による交通追加交 付金(Transport Supplementary Grant: TSG)の獲得)できるよ うになった. TPP の導入により, 理屈の上では, 道路交通と 公共交通のバランスに配慮した効率的な投資が可能になる はずであったが, 現実には，ほぼ道路投資だけがその対象 となり，しかも TSG 予算の削减によりその投資額が軒並み低 下した.このため多くの地方自治体は, 道路整備の予算獲 得のために, 都市開発公社を通した再開発事業予算や欧州 共同体からの基金を活用せざるを得ない状況となった. 一 方で, 公共交通については, 1986 年にサッチャー政権の方 針で, 域内バス事業の規制緩和が行われたため, 地方部に おいて公共サービス水準の低下が深刻となった.このため 1990 年代には, 道路整備や公共交通投資, 交通需要マネ ジメント等の関連施策を同時に考虑するパッケージ・アプロ 一千の必要性が唱えられるようになった. やはり，この考え 方は, 「総合化」を好む労働党政権の交通政策にも引き継が れ，地方交通のシステム改善へとつながっていにととなっ た.

\section{3. ブレア労㗢党政権下での交通政策}

\section{(1)1997 年以降の交通政策の変化}

1997 年, ブレア首相率いる労㗢党(ニューレイバー)は, 18 年ぶりに政権に復帰した. ニューレイバーの特徴の一つ は, 従来の労㗢党が持っていた教条的な左翼思想を捨て, 


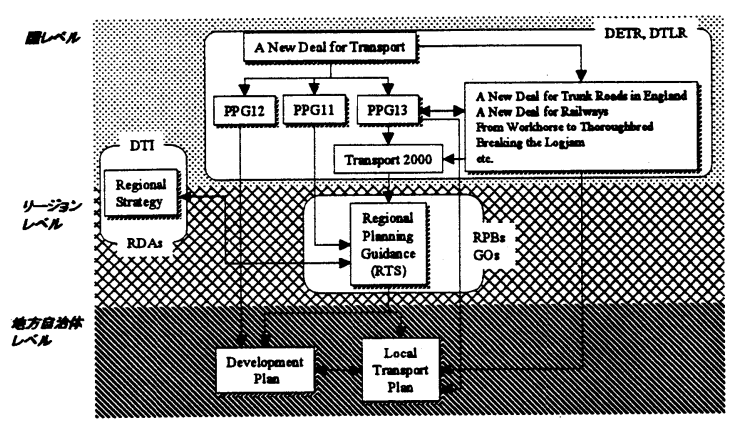

図-2 英国の交通関連の計画, 政策ガイダンスの関係図

注:各種資料上り啭者ら作成

市場原理を最大限に活用しつつ総合的な施策を提案して いることにあるといわれる ${ }^{8)}$. 交通政策に関しては, 1997 年

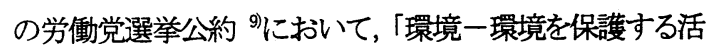
動を進め, 総合的な交通体系 (公共交通促進や自動車交通 抑制)を発展させる」ことが示されていた. さらに, ブレアの 片腕であり副首相でもあるジョン・プレスコット氏が, 交通問 題に強い関心を持ち, 交通を担当する環境交通地域省 (Department of Environment, Transport and the Regions: DETR)の大臣となったことから，ニューレイバーは交通に対 してかなり積極的かつ迅速に改革を進めることになった.

まず, DETRは, 1998 年7月, 20 年ぶりの交通白書 ${ }^{10} を$ 表した.この白書は, その後現在(執筆時点は 2002 年)に至 るまで, 英国内で実施されてきているあらゆる交通政策の基 本となっているものである. 続いて, 交通白書をさらに梁く検 討した「娘文書」と呼ばれる文書や関連する協議書, 白書が 立て続けに発表された.ここでは, 幹線道路 ${ }^{12 か ら ら ゙ ス ~}{ }^{12)}$, 鉄道 ${ }^{13)}$, 物流 ${ }^{14)}$, 通勤交通の環境計画 ${ }^{15)}$, 空港アクセス交通 ${ }^{16} に$ にたるまで多岐にわたる交通サービスの問題点の整理 之問題解決に向けた政策提案がなされた. これらを受けて, 2000 年11月には, 地方交通計画, ロードプライシング•職場 駐車場課金, バスサービスの品質協定ならびに品質契約, 戦略的鉄道委員会の導入等を定めた 2000 年交通法 (Transport Act 2000) ${ }^{17}$ が制定された. さらに, DETR は, 2000 年 7 月に交通政策の実行計画に当たる「10 箇年計画」 (Ten year Plan) $)^{18)}$ を発表した. この計画では, 官民合わせて 1,800 億ポンドの支出が計画されており,これは 1990 年代の 10 年間の総投資額と比較して, ほぼ 75\%もの増強にあたる. 大幅な投資増強に対しては，国内でも賛否両論があるよう だが，いずれにせよ英国における過去の交通投資の縮小 傾向から見れば,これは画期的な予算計画であることには 間違いない.

以上のように, 交通白書発表から, 法律制定, 実行計画 (10 箇年計画)発表まで, わずかに 2 年あまりしかかかって いない.いかに迅速に改革が進められたかがわかる。

\section{(2)ブレア政権の交通政策の特徽}

ブレア政権の交通政策の基本は, 1990 年代前半に提唱
された「新現実主義(New Realism)」と呼ばれる考え方にある と言われる ${ }^{19) 200}$. 新現実主義とは, 包括的かつ総合的な交 通政策へのアプローチのことであり，(1)自家用車利用から 改善·拡張された公共交通への計画的なシフト, (2)歩行者, 自転車利用者, その他環境に優しい交通手段の提供, (3)通 過交通量の最大化よりむしろ自動車速度の低下と旅行時間 の信頼性向上を目的とした交通静寂化, 交通規制, 交通需 要マネジメント(4)リップ長並びに無用な交通発生の削減の ための土地利用計画と開発規制を含むものと定義される.

ニューレイバーの交通政策の特徽は, 新現実主義で示さ れるような「総合化」に加え,「官民協力・調整」「経済的交 通需要マネジメント,「地方分権」といらた点にも見られる. そこで, 以下にこれらの特徵点に沿って, 各種政策を整理 することとする.

\section{1)総合化(integration)}

交通白書では，次の $4 つ の$ 総合化(連携)が揭げられてい る:(1)異なるタイプの交通間の連携(各交通モードの可能性 を完全に引き出し, 人々の交通モード間移動を容易化), (2) 環境との連携(交通の選択により良好な環境を形成)，(3)土 地利用計画との連携(全国, 地方及び地域の各レベルで, 交通と土地利用計画が相俟って, より持続可能な移動手段 が選択され，また移動の必要性を低减)，(4)教育, 健康及び 富の創造のための施策との連携(交通が, より公正で参加可 能な社会を実現). 各連携に含まれる具体的施策の例を, 表 としてまとめたものが表-1である.

表-1:交通白書の4つの連擭と具体的施策例

\begin{tabular}{|c|c|}
\hline 連勇のタイフ & 具体的塩重例 \\
\hline $\begin{array}{l}\text { (1)異なるタイプの交 } \\
\text { 通間の連搭 }\end{array}$ & 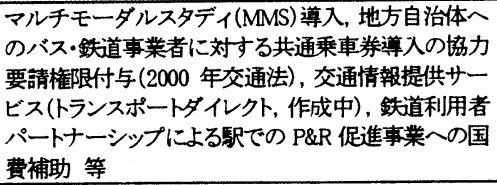 \\
\hline (2)堛境との連掽 & 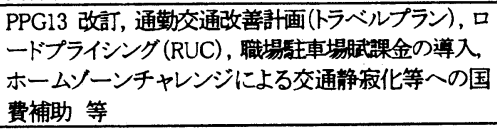 \\
\hline $\begin{array}{l}\text { (3)土地利用計画と } \\
\text { の連搭 }\end{array}$ & $\begin{array}{l}\text { PPG11, PPG12, PPG13 の改訂, 地方交通計画の予 } \\
\text { 算配分時での開発計画との連㩲考虚，等 }\end{array}$ \\
\hline $\begin{array}{l}\text { (4)教育, 健康及び } \\
\text { 富の創造のため } \\
\text { の施策との連撘 }\end{array}$ & 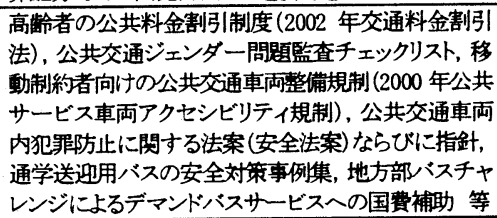 \\
\hline
\end{tabular}

注:各種資料より筆者ら作成

いずれも, 使われる用語こそ異なるが,「交通のシームレ ス化」,「環境負荷軽减」「「交通とまちづくり・都市計画との連 携」,「バリアフリー化」等として, 我が国でも交通政策の重要 項目として挙げられるものばかりである. 表-1であげた具体 的施策例はあくはでも全体の一部でしかないが，4つの「総 
表-2 交通プロジェクトの評価基準(NATA)

\begin{tabular}{|c|c|c|c|}
\hline 太哽目 & \multicolumn{3}{|c|}{ 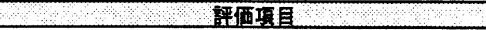 } \\
\hline 羁境 & $\begin{array}{l}\text { 證音 } \\
\text { 景哯 } \\
\text { 水環境 }\end{array}$ & $\begin{array}{l}\text { 地方の大気质 } \\
\text { 歷史的遺産 } \\
\text { 物理的適合性 }\end{array}$ & $\begin{array}{l}\text { 温室効果ガス } \\
\text { 生物多様性 } \\
\text { 旅行快道性 }\end{array}$ \\
\hline 安全 & 事故 & 治安 & \\
\hline 経済 & 絴済効率性 & 安定性 & 地域䋽济効果 \\
\hline アクセシビリティ & オプション価值 & 地域分断 & 交通施設へのアクセス \\
\hline 紾合化 & 交通結節点 & 土地利用政策 & 他分野の政策 \\
\hline
\end{tabular}

注: 文献 48)より引用

合化」項目間で比較すると,「(3)土地利用計画との連携」の 具体策が最も少ないように思われる. なお,ここには含まれ ていないが, ブレア政権誕生まで分かれていた交通省と環 境省を統合してDETRを発足させたことも一つの「総合化」と 言えるかもしれない（ただし, その後, 交通・地方政府·地 域省(Department of Transport Local government and the Regions))へと組織改正され, 現在は交通省(Department for Transport)に逆戻りした)ブレア政権は, 交通の「総合化」を 押し進める上で, 交通プロジェク外の評価方法にも大きな変 更を加えている. 1998 年に新たな評価手法アプローチ (New Approach to Appraisal: NATA) $)^{21}$ を導入し, 従来までの 費用便益分析をべースとする評価方法(英国では COBA と 乎ばれる手法が長い間用いられている)を抁張し，環境や 総合性をも評価しうる新たな評価基準を提案した. その評価 項目を整理したものが, 表-2 である.これにより, ブレア政 権の掲げる主要な政策が, 事業の評価にも反映できるように なった.

\section{2）官民協力, 調整}

公共と民間のパートナーシシプならびに公共による民間 サービスの調整は, ブレア政権における交通政策の重要な 柱である.

まず, バスサービスにおいては,「品質協定」(Quality Partnership),「品質契約」(Quality Contract)が 2000 年交通 法によって正式に導入され，地方自治体とバス事業者が互 いにバスサービス向上のために協力するという仕組みが整 備された.「品質協定」とは, 地方自治体とバス事業者との間 でサービス内容(例えば, 自治体がバス専用レーンを整備 する代わりに事業者が運行本数を増やす等)に関して非公 式な取り決めを行うものであり,すでに1990年代前半頃から

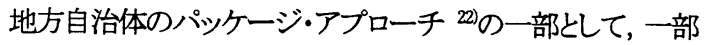
の自治体では実施されていたものである. 一方で,「品質契 約」とは, 基本的には「品質協定」と同じ目的を持つものだが, 消費者代表ならびに中央政府の承認の下, 入札を通じて決 定された特定の事業者之自治体之が独占的な契約を結ぶも のである. いずれも, バスサービスの改善によって, 自動車 からバスへの転換の促進, 人々の移動機会確保, 交通選択 ひ幅拡大を目指寸ものである. 我が国でも, 都道府県が中 心となって地域協議会を設置し, バスサービス確保の検討 をすることが提案された(運輸政策審議会答申 ${ }^{23}$ ) が, これ は品質協定に近い仕組みであるといえるであろう ${ }^{24)}$.

一方, 鉄道では, 戦略鉄道委員会(Strategic Rail Authority:
SRA)が新たに導入され, より効果的で明確な責任の下にお ける鉄道サービス規制の実現ならびに鉄道整備の長期計 画策定のための権限が付与された ${ }^{202060}$. 英国では1993年鉄 道法による英国国鉄の民営化以降, 上下分離, 客貨分離, 旅客サービスの競争入札によるフランチャイズ制が適用さ れてきたが, 相次ぐ大事故の発生, 施設の老朽化, 遅延の 慢性化等が深刻な問題となり, 安全性確保ならびにサービ ス向上が重要課題として取り上げられていた. 2000 年交通 法により, SRA は旅客・貨物の両方を対象に, 免許違反やフ ランチャイズ協定への違反を行う民営事業者に対して制裁 金を課す権限が与えられたほか,「10 箇年計画」では狭㿽 区間に対する容量拡大等の長期的な投資に向けた予算が 提案されている27.

\section{3)経斉的交通需要マネジメント}

ブレア政権は，地方自治体が実施するロードプライシング (Road User Charging: RUC) と職場駐車場課金 (Workplace Parking Levy: WPL)を 2000 年交通法の中で制度化した ${ }^{232,29)}$. これは, 英国の交通政策にとっては画期的な事柄である. なぜならば, 英国ではロードプライシングを世界に先駆けて 議論, 検討してきたにもかかかからず, 技術的, 政治的な理由 から他国(シンガポールやルルウェー)に先んじられてきた からである. 2000 年交通法では, 地方自治体に対し, 独自 にRUCあるいは WCL を導入する権限が与えられた. ダー ラム, ダービシャー, リーズ, ブリストルの自治体が RUC を, ケンブリッジ, ハッティンガム等が WPL を検討しており, ダー ラムでは他都市に先駆けて 2002 年 10 月より RUC が導入さ れた. ロンドンについては, グレーターロンドン庁 (Greater London Authority: GLA)が設立されるにあたり, 1999 年グレ ーターロンドン庁法により, ロンドン交通局にロードプライシ ング(ただし，ロンドンでは混雑課金(コンジェスチョンチャ 一ジング)と呼ばれている)の課金権限が付与された. ケン. リビングストン現市長は, 混雑課金導入を公約として当選し た経緯があるため, 都心部への混杂隹課金導入の検討が積 極的に進められており，2003 年 2 月より運用が開始された. 市民, 関係諸機関あるいは業界との合意形成に時間のかか るロードプライシンングがロンドンで比較的早く達成された理 由としては, (1)過去に十分な検討が多角的かつ深くなされ 議論が尽くされていたこと, (2)ロンドンでは, 市長に大きな 権限が与えられているため, 市民からの支持があれば強引 でも政策実行が可能なこと, (3)導入反対の根拠としてしばし ば他都市との競争力の低下が懸念されていたが, 現在英国 経済が順調に推移しロンドンの活力が高まっているため, 導 入によって大きな経済的ダメージを受けるという印象が薄れ たこと, (4)ロンドン都心部の混雑問題が深刻であり, その対 策の重要性が市民の共通認識として醇成されていたこと等 が挙げられるであろう.

\section{4)地方分権}

ニューレイバーは，その発足当初から地方分権を強く押 
進めている. まず, 1998 年以前の幹線道路ネットワークの約 40\%が地方自治体に委譲された ${ }^{11)}$. また, 2000 年交通法によ って, 地方自治体は，RUCやWPLを独自に導入し，その収 入を地方自治体内の交通投資にあてることができるようにな った.これは, 従来, 英国では, 地方自治体は中央政府から の補助金に強く依存する体質であった ${ }^{30}, 31$ ことを鑑みると， 地方自治体が独自財源を持てるようになったことは注目に 值する. また, ニューレイバーは, 交通だけでなく政策全般 に関して, 国から region 一様々な機能を委譲させようとして いる点にも着目すべき点である ${ }^{32} .1997$ 年の総選挙におけ る労㗢党の選挙公約 9)では, 「Englandでは, region 単位の議 会に対する需要がかなり大きいので, 連合という仕組みを強 制することは誤りかもしれない, region ごとに, 直接選挙によ つて選ばれる議会を持つべきか砧かを, 住民が Referendum によって決定できる法律を, 近いうちに導入する」と述べら れている. そして, 1999 年にScotland とWales が権限委譲さ れたのを受けて, England 内の他の region においても, 独立 に向けた動きが出始めている. なお, Regional Government の導入可能性については, 中央政府等によって現在検討が 進められつつある.

\section{4. 英国の交通計画システムの仕組みとその変化}

本章では, 英国の交通計画システムについて,まず国と 地方といら観点から整理し, 次にブレア政権が現在, 鋭意導 入を進めつつある region 単位の計画システムの概要につい て述べる. その後, ブレア政権の政策によって, 交通計画シ
ステムがどのように変化しつつあるかについて検討する.

\section{1 英国の交通計画における国と地方の役割}

(1)交通計画における国の役割

英国の交通計画に関連する国の役割は，大きく分けると， 表-3のように分類できる.

以下に, それぞれの国の役割を示す.

(1)交通政策, ガイドラインに関する文書の作成

先に述べたように，英国には，国家的プロジェクトの推進， 分野間・地域間での社会基盤(交通基盤を含む)投資調整， 土地利用の調整といった複数の機能を合わせ持つ国主導 の全国計画は存在しない. その代わり中央政府は, 交通白 書をはじめとする各種文書を発表することで他分野や地域 間・階層間公平性に配慮した交通政策の理念を示すととも に, その交通政策に地方自治体を従わせるためのガイドラ イン $(\mathrm{PPG13})^{33)}$ を策定している.

まず英国の白書は, 我が国の白書とは相当に趣の異なる ものである. 時の政権の考えが強く反映されるものであり, 特に今回のブレア政権誕生のような保守党から労働党への 政権交代のケースでは, 白書は具体的な政策表明の場とも なっている. また白書では, たとえ詳細が(表向きは)定まっ ていない内容のものであっても, 大枠レベルの政策提案が 積極的になされるのも特徵である.にもかかわらず, 白書で 提示された内容は, かなりの部分が, 制度改变や予算配分, 新組織設立等によって実行に移されるため, 実質的な政策 文書の役割も実質的に担っているといえるであろう. また, 政策提案文書だけでなく, 地方自治体や関連機関が守るべ

\section{表-3 英国の交通計画に関する国の役割とそのブレア政権登場後の変化}

\begin{tabular}{|c|c|c|}
\hline 国の役割 & 特缽 & フレア政椎登塧後の变化 \\
\hline $\begin{array}{l}\text { (1)交通政策の理念の提示 } \\
\text { ならひにこれに沿ったガイ } \\
\text { ドライン, 通達, 事例集等 } \\
\text { の文書の策定 }\end{array}$ & 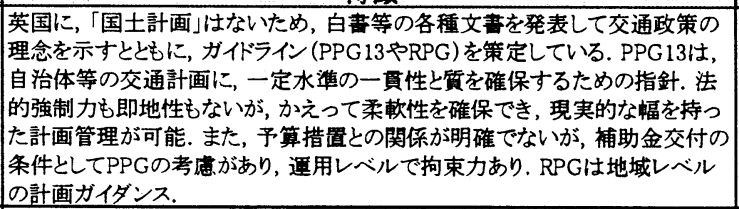 & $\begin{array}{l}\text { PPGの見直し. PPG11をRPG向けに変更. } \\
\text { RPG案の策定を, 自治体の連合体組織であ } \\
\text { るRPBに委任. ただし, 最終的な発行は大臣 } \\
\text { が行う. 白書, 協議茟等をあまりに大量に発 } \\
\text { 行しているため, 関係者が正しく把握している } \\
\text { かは問題. }\end{array}$ \\
\hline $\begin{array}{l}\text { (2)地域整備局 } \\
\text { (Government Office for } \\
\text { the Regions) 等を通じた地 } \\
\text { 域計画ガイダンス策定なら } \\
\text { びに関連機関への指道 }\end{array}$ & $\begin{array}{l}\text { GOは, 1994年に境交通地城省, 通商産業省, 教育雇用省の出先機関を統 } \\
\text { 合して設立された, 地域の住宅, 計画, 交通等の担当機関. マルチモーダル } \\
\text { スタディの実施, 地方交通計画策定時の国と自治体との連絡役, 道路庁を通 } \\
\text { して地方交通計画中の道路整備投資額を変更するようアドバイス, テーータ収 } \\
\text { 集,調查分析等を行う. }\end{array}$ & $\begin{array}{l}\text { 地域の経済開発を主迸する目的で, 地域開 } \\
\text { 発庁(RDA)が設圈される. GOの位置つつけ } \\
\text { は, 低くなった可能性有り. }\end{array}$ \\
\hline $\begin{array}{l}\text { (3)交通関連予算計画策定 } \\
\text { ならひに補助金等の交付 }\end{array}$ & $\begin{array}{l}\text { 英国では, 自治体の自主財源が相当に限定される一方で, 国に特別会計制 } \\
\text { 度がないため, 自治体による交通投資の大部分は, 中央政府の一般会計か } \\
\text { らの補助あるいは地方僨によって賄われている. }\end{array}$ & $\begin{array}{l}\text { 「10箇年計画」に沿って個別事業への補助金 } \\
\text { 等決定. 都市部・地方部バスチャレンジや鉄 } \\
\text { 道利用者パートナーシップ等の新たなプログ } \\
\text { ラムを開始. 地方交通への予算増強. } \\
\end{array}$ \\
\hline $\begin{array}{l}\text { (4)高速道路, 幹線道路の } \\
\text { 計画策定 }\end{array}$ & $\begin{array}{l}\text { 地域レベルで行われるマルチモーダルスタディ(MMS) 等の検討を通じて高 } \\
\text { 速道路, 幹線道路網の計画を策定. 計画は, 道路庁によって事業化·建設が } \\
\text { なされる. }\end{array}$ & $\begin{array}{l}\text { マルチモータルスタディの成果の一部を「10 } \\
\text { 箇年計画」に盛り込んだ. 幹線道路整備予算 } \\
\text { は，增強された. }\end{array}$ \\
\hline $\begin{array}{l}\text { (5)公共交通事業者, 運送 } \\
\text { 事業者等の規制等 }\end{array}$ & $\begin{array}{l}\text { 規制緩和が進んでいるが, 安全性確保のための規制は依然として残されてい } \\
\text { る. (例:鉄道規制庁(ORR)による免許規制) }\end{array}$ & $\begin{array}{l}\text { バスは, 品質協定, 品復契約導入により官民 } \\
\text { パートナーシップを強化. 鉄道は, SRAにより } \\
\text { 一部規制を強化. }\end{array}$ \\
\hline $\begin{array}{l}\text { 6)大臣による市民からの計 } \\
\text { 画に対する不服申し立て } \\
\text { 審査しならひに必要に応し } \\
\text { て自治体の計画への直接 } \\
\text { 介入 }\end{array}$ & $\begin{array}{l}\text { 幹線道路整備では, 道路庁が国を代行して手続きを進め, 公開害問会等に } \\
\text { お゙いて不服のし立てが合った場合, 審問官の勧告を通じて大臣が最終決 } \\
\text { 定を下す. 地方道路整備でも, 大臣の不服申し立て審査は幹線道路と同様 } \\
\text { だが,さらに強制的に計画手続に介入して計画修正を求める権利が大臣に } \\
\text { 付与される. }\end{array}$ & 特に変更無し \\
\hline
\end{tabular}


きルールを記載したマニュアルや事例集も，中央政府から 数多く発行されている.ただし，あまりに多くの，しかも大部 な文書が短期間に次々と発表されるため, 自治体へのヒヤリ ング等によれば，一部の関連する地方自治体等の担当者は, 十分に理解し切れていない可能性があるのも事赛である.

一方で, PPG13 は, 一連の PPG 群の1つであり, 地方自 治体の策定する交通計画に, 主に環境保全の視点から一定 水準の一貫性と質を確保することを目的とした中央政府のガ イドインである. PPG には法的強制力も即地性もないが, それがゆえにかえって柔軟性を確保でき，ある程度現実的 な幅を持った計画の管理が可能であると言われている ${ }^{34)}$. ただし，交通基盤の整備に関しては, ガイドラインに沿った 交通計画だけがあっても意味が無く, それに呼応した予算 システムが用意されていなければならない. その点で PPG は, 単なるガイドラインであって予算措置との関係が明確に ないことが一つの久点との指摘もある. だが, 実際には, 国 から地方自治体一の補助金交付の条件として, ガイドライン の考慮が措置を行うことが示されており，運用レベルにおい てPPG はある程度拘束力のあるものと考えられる。

\section{(2)予算計画の作成と補助金交付}

英国では, 一般に地方自治体の自主財源が相当に限定 されている一方で, 国は交通に特化した特別会計制度が存 在しないため, 地方自治体による交通投資のかなりの部分 は, 中央政府の一般会計からの補助あるいは地方債によっ てまかなわれている ${ }^{30,31)}$. 中央政府の交通政策実行計画と しては,「10 箇年計画」が策定されており, 原則的にはこの 長期予算計画に沿って, 各年度の個别事業あるいは地方自 治体への予算配分を行うといらやり方をとっている.

\section{(3)高速道路・幹線道路の整備}

以上のような地方自治体を対象とした交通政策, ガイダン スに加えて, 国の直轄プロジェクトとしては, 高速道路·幹線 道路の整備も行われている. 高速道路, 幹線道路網の計画 は，地域レベルで行われるマルチモーダルスタディ

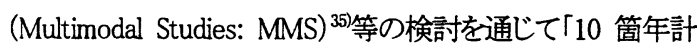
画」の中に盛り込まれる.これらの計画は, 最終的には道路 庁(Highways Agency: HA)によって事業化され建設がなさ れる. なお, 1995 年度以降の幹線道路予算は数年間にわた り削減されていたが, 先の「10箇年計画」によると, 2001 年度 以降, 削減前とほぼ同額あるいはそれ以上の国の予算が幹 線道路整備に当てられることとなった.この点に関しては, 道路から公共交通, 徒歩, 自転車へのモーダルシフトを打 ち出している政府の全体政策と矛盾がないわけではない。

(4)公共交通事業者, 運送事業者等に対する安全規制

基本的に英国は規制緩和の先進国であり, バス，鉄道の 規制緩和が 1980 年代から 90 年代はじめにかけて行われた。 したがって, 主にサービス水準の確保を目的しして, 官民パ ートナーシップが盛んに実施されているのは先に述べたと おりである. ただし, 多くの安全確保のための規制は依然と
して残されており, 例えば, 鉄道では鉄道規制庁(Office of the Rail Regulator: ORR)による免許規制が行われている. (5)開発計画の不服申立て審査と自治体計画一の強制介入 交通施設の計画は, 最終的には地方自治体の策定する開 発計画の中に組み込まれる. 幹線道路整備については, 国 の事業であるからHAが国を代行して手続きを進め, 公開審 問会等において不服の申し立てが合った場合, 審問官(イ ンスペクター)の勧告を通じて大臣が最終決定を下す。一方, 地方道路整備については, 地方自治体がDPの中で計画策 定するものであるため, 通常の DP 策定の手続きに沿つて, 公開審問会や公開討議を経て関係主体間の調整, 住民参 加がなされる. 大臣が不服申し立ての審査を行うことは幹線 道路と同様だが, 地方道路の場合には,さらに強制的に計 画手続に介入(コールイン)して計画修正を求める権利が大 臣に付与されている.ただし, 大臣が強制介入の権限を執 行することはかなり稀と言われる。

\section{(2)地方自治体の交通計画}

英国の地方自治体は，一層制(単一カウンシル)と二層制 (カウンティとディストリクト)が混在する仕組みとなっている が, 交通計画の策定を担っている(交通計画部局)のは, 前 者では単一カウンシル, 後者ではカウンティである. 単一カ ウンシルとカウンティは我が国の都道府県, ディストリクトは 市町村にあたると考えればよい ${ }^{36}$.

2000 年交通法により, 英国の全ての交通計画庁は, 従来 の交通政策プログラム(TPP)に代わり, 地方交通計画(Local Transport Plan: LTP)を策定することが義務づけられた ${ }^{37}$. TPPとLTPの違いを整理したものが, 表-4である ${ }^{38}$. 両者の 最大の違いは, 対象期間が 5 年となったことと, 中央政府か

\section{表-4 英国地方自治体の交通計画システムの変化 ${ }^{380}$}

\begin{tabular}{|c|c|c|}
\hline & TPPs & LTP \\
\hline 期間 & 1年 & $\begin{array}{l}\text { 5年（地方交通当局にとつ } \\
\text { ての将来支出に対する確 } \\
\text { 実性増) }\end{array}$ \\
\hline 機能 & $\begin{array}{l}\text { 中央政府からの资金獲得 } \\
\text { のための入札㗄料 }\end{array}$ & $\begin{array}{l}\text { 资金獲得のための入札资 } \\
\text { 料であるとともに，将来5年 } \\
\text { 間の地方交通の戦略的な } \\
\text { 計画 }\end{array}$ \\
\hline 対象支出 & 資本支出のみ & $\begin{array}{l}\text { 资本支出のみを対象とす } \\
\text { るが，その配分に関して畆 } \\
\text { 本支出と地方当局収益支 } \\
\text { 出の使途の両方を考虑 }\end{array}$ \\
\hline $\begin{array}{l}\text { 地方 当 局の } \\
\text { 裁量䇷囲 }\end{array}$ & 特定分野への资源配分 & $\begin{array}{l}\text { 资源配分に関する地方当 } \\
\text { 局へのより大き裁量付与 } \\
\text { (中央政府方針の筑囲内 } \\
\text { で) }\end{array}$ \\
\hline $\begin{array}{l}\text { 関倸主体の } \\
\text { 参加 }\end{array}$ & 限定的な計画決定 & $\begin{array}{l}\text { 交通事業者や市民, 一般 } \\
\text { 事業者等の㮴極的関与の } \\
\text { 推奖 }\end{array}$ \\
\hline 目標 & $\begin{array}{l}\text { 広簀な目標設定(パッケー } \\
\text { ジアプローチを除く) }\end{array}$ & 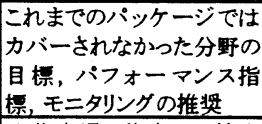 \\
\hline \begin{tabular}{|l} 
力点の掼か冯 \\
万交通機関
\end{tabular} & \begin{tabular}{|l} 
自動車以外の手段利用奖 \\
励施策へのシフトはある \\
が，基本は道路
\end{tabular} & $\begin{array}{l}\text { 公共交通, 徒歩, 二陯車 } \\
\text { の利用を推奖 }\end{array}$ \\
\hline
\end{tabular}




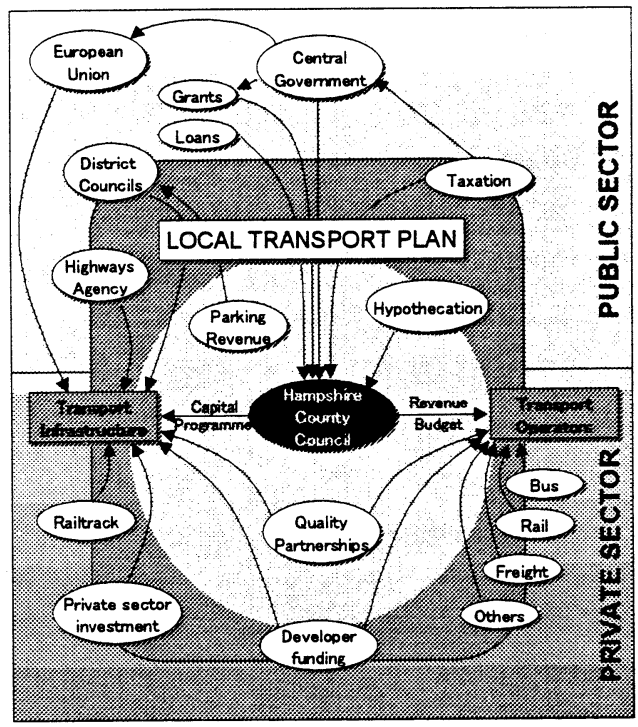

図-4 : 地方交通計画をめぐる資金フロ一の概略 (Hampshire County Council $の$ (例) ${ }^{39}$

らの補助金が特定目的限定(ひも付き)ではなく, 大規模事 業以外については, 比較的自由に使途を自治体が決定で きるブロック補助となったことである. ただし, 地方交通計画 は, 中央政府の示す政策やガイドライン(PPG)あるいは地 域単位のガイドラインである地域計画方針ガイダンス (Regional Planning Guidance: RPG)等と政策の方向性が合致 していることが要求されており,この要求を守らない場合に は, 中央政府の裁量で, 補助金が交付されない可能性が発 生する.

なお，地方自治体は，自らの税収入や他の競争的基金 (EUの構造基金や都市部・地方部バスチャレンジ等)を活用 することができる. Hampshire County Council を例に, 地方 自治体における交通計画をめぐる資金の流れの概略を示し たものが, 図-4である ${ }^{39)}$.

筆者らのヒヤリングによれば, 地方自治体では, 2000 年交 通法により, LTP が導入されたが, 新ンステムに対する理解 度やそれに向けた対応は, 自治体によってずいぶん温度 差があるようであった。

\section{2 地域(region)レベルの交通戦略の導入とその実態}

近年, 英国では, 空間計画あるいは交通計画の要として地 域(region)における計画の重要性が増しつつある. そこで, 以下では, region の交通計画に関与する主体を整理し, 次 にregion 単位で策定されている各種計画の概要について整 理する.

\section{(1)Region における交通計画の関連組織の概要}

1) Government Offices for the Regions $(\mathrm{GOs})^{40)}$

GO は中央政府から各 region への出先機関であり, 1994 年に, それまでの DETR, 通商産業省(Department of Trade

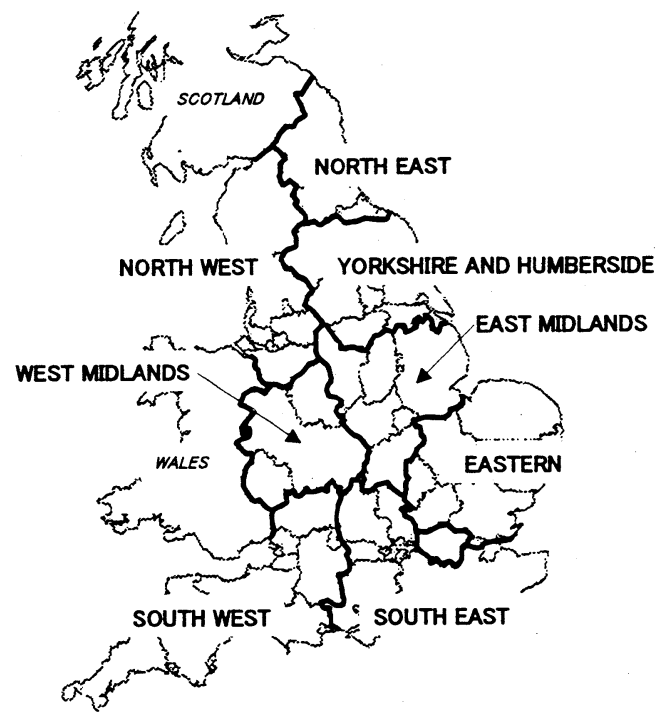

图-5 England $の$ Region の位置

and Industry: DTI), 教育雇用省(Department for Education and Employment)の出先機関を統合する形で設立された. region レベルの住宅, 計画, 交通等を主に担当する. 主に, LTP 策定に当たって中央政府と地方自治体との連絡をした り, RPG 策定に当たって地域開発庁(Regional Development Agency: RDA)や地域計画機構(Regional Planning Body: RPB) との調整を行ったりする. また, GOはHA を通して, 各地方 自治体の策定するLTP中の道路整備投資額を変更するよう アドバイスするなど, 行政指導を行ったり,データ収集, 調 查分析に関しても, 関係主体と協力を行う ${ }^{41.42}$.

筆者らのヒヤリングによれば, やはり GOはあくまでも中央 政府の出先機関であって, 中央政府の政策方針とほぼ $100 \%$ 合致した指導を, 関係主体に行っている, とのことであった。 また, 下記の RDA 等の設置により, その役割が低下つつ あるとの印象を受けた。

2) Regional Development Agencies (RDAs) ${ }^{43), 44}$

RDAは1999年(ロンドンについては, 2000 年)に新たに設 置された region 単位の機関である. その法的根拠は, 1998 年地域開発庁法(Regional Development Agencies Act 1998) にあり, DTI が管轄省である. その法律上の目的は, 経済開 発·再開発の推進, 経済的効率性·競争力の向上, 雇用の 促進, 職業技能の教育, 持続可能な発展への貢献にある. 各エリアの競争力を高め, region間あるいは region内での経 済格差を解消することが策定された意図とされる.

RDA 設立の背景には, region 単位での意思決定にむけ た,つまり地方分権への重要なステップという位置つけがあ る. RDA はあくまでも国の機関であるものの, region の利害 を代表するという目的も担っている. このため, 中央省庁か らは独立した機関と位置づけられている。

さらに, RDAの活動を監視, サポートすることを目的として, 
RDA Act 1998 に基づき, region 内の関連地方自治体や商 業関係者から構成される Regional Chamber (実際には, Regional Assembly 等の名前が使われていることが多い. )が 設置可能となった. ただし, Regional Chamber はあくまでも 自主的な組織であり，指名されるという限界がある. またロン ドン(Greater London: GL) 以外の regionについては, メンバ 一が担当大臣によって期待通りに機能していないとの指摘 もある.

各RDAは, 基本的な考え方(RDAs Regional Strategies)に 沿って, 地域戦略(Regional Strategy: RS)を策定する. RS に おいては, RPG とも連携をとりながら, 交通, 土地利用計画 等についても言及がなされる. しかし，現在のシステムでは， RPG の策定之 RS の策定は必ずしも同時に行われるわけで はないため, 内容に関して相互に配慮はなされるものの, 一致する保証はなく, 両者間の整合性確保は, 担当者の努 カに依存しているようである.

RDA の性格は, regionによってずいぶん異なるようである. 筆者らのヒヤリングによれば, NorthEast の RDA では, 比較 的大規模な予算を活用して, 企業誘致等に向けて積極的な 活動を行っているが, SouthEastのRDAでは，投資規模も小 さく, 既存市街地の活性化等のプロジェクトが主であった.

3) Regional Planning Body (RPB) ${ }^{45}$

RPB は, RPG の案(draft)を策定する主体である. 以前は, RPB は関連する地方自治体により構成される region 単位の 会議(regional conference)であることが多かった. だが, 先に 述べたように, RDA Act 1998 に基づいて Regional Chamber が設置され，自治体間の調整機能の役割を引き継いだため, RPBも一部の region では Regional Chamber に移管されてい る. なお, Regional Chamberメンバーのうち, 70\%は地方自治 体, 残りは他の関係機関から構成されることとされる. ただし, 筆者らのヒヤリングによれば, 実際には RPB のスタッフはか なり少なく(NorthWest ではわずか数名が交通部門を担当し ていた), またほとんどが地方自治体からの出向者のため, regionレベルでの計画の経験も浅いことから, RPBの機能性 にはやや疑問を感じた.

\section{(2) Regional Planning Guidance(PPG)}

RPG は, PPG, 採掘方針ガイダンス(Minerals Planning Guidance: MPG)Lしもに 1988 年以来, 中央政府によって策 定されてきた region レベルでの空間計画戦略である. RPG に関して中央政府が定める計画方針ガイダンスは PPG1146) である. だが, 従来の RPG があまりにトップダウン的に策定 されすぎて region の視点が欠けていたこと, 土地利用に偏 った検討がなされていたこと, 計画策定手続きに要する時 間が長すぎること, といらた批判か あった ${ }^{47}$. そこで, 中央政 府は, ボトムアップ式に regionレベルの戦略が策定可能とな るよう, RPG システムの抜本的な改革を提案した. それに伴 い, PPG11 は 2000 年 10 月に改訂がなされた。

\section{表-5 各 region の RDA と regional chamber}

\begin{tabular}{|c|c|c|}
\hline Region & RDA & Regional Chamber \\
\hline Eastern & East of England & East of England Regional Chamber \\
\hline East Midlands & East Midlands & $\begin{array}{l}\text { East Midlands Regional Local } \\
\text { Government Association }\end{array}$ \\
\hline North-East & One North-East & $\begin{array}{l}\text { North of England Assembly of } \\
\text { Local Authorities }\end{array}$ \\
\hline North-West & North-West & North-West Assembly \\
\hline South-East & South-East & $\begin{array}{l}\text { South-East England Regional } \\
\text { Assembly }\end{array}$ \\
\hline South-West & South-West & South-West Planning Conference \\
\hline West Midslands & $\begin{array}{l}\text { Advantage West } \\
\text { Midlands }\end{array}$ & $\begin{array}{l}\text { West Midlands Local Government } \\
\text { Association }\end{array}$ \\
\hline $\begin{array}{l}\text { Yorkshire and } \\
\text { Humberside }\end{array}$ & Yorkshire Forward & $\begin{array}{l}\text { Regional Assembly for Yorkshire } \\
\text { and Humberside }\end{array}$ \\
\hline
\end{tabular}

注: 文献 47)より引用

RPG の主な目的は，地方自治体が，DPならびにLTP を 策定するための上位計画戦略を提示することにある. 対象 期間は, 15-20 年である. そのカバーする範用は, 住宅, 環 境, 交通, 経済開発, 農業, 鉱業, 廃棄物と多岐にわたる. RPG は RPB によって, その案が策定され, 公開討議(Public Examination)を経て最終的に担当大臣(Secretary of State)に よって発行される. RPG では, 多分野にわたる長期計画戦 略が記述されるが, 今回の PPG11 の改訂に伴い, 交通に関 しては, 特に地域交通戦略(Regional Transport Strategy: RTS)として, 独立した計画戦略が策定されることとなった.

なお, NorthEast の RDA へのヒヤリングによれば, 現時点 における RPG は, 単なる地方自治体の計画の寄せ集めに なっている可能性が高いという. したがって, 今後 RPG が真 に上位計画としての機能を果たせるかどうかについては, 注意が必要と思われる.

\section{(3) Regional Transport Strategy (RTS)}

RTS は, 新交通白書の中で提案がなされ, PPG11 の改訂 によって新たに RPGの中で策定されることとなった regionレ ベルの交通戦略である. RTSは, region 内の全交通機関を 対象とした交通投資·運営の優先順位や, 鉄道·空港・港湾 の開発促進戦略, 交通利用選択肢の抗大施策(特に鉄道と バスの統合), DPやLTP で設定される公共交通のサービス レベルの設定, LTP で実施される交通需要マネジメント(駐 車場の設置基淮等)に関する指針等を定めるものである.

RTS は, LTP の上位計画にあたり, LTP 面積だけでなく, 期間の点でもカバーするものである. 一方で, RTS の上位 計画としては, 国の長期総合交通計画である「10箅年計画」 が該当すると考えられる. なお, RTS 策定に当たっては, 以 下で述べるMMS (Multi Modal Studies)に基づいた分析結果 を参考にしなければならないこととされる。

\section{(4) Multi-Modal Studies (MMS) ${ }^{30}$}

MMS は, 広域の視点から見て特に深刻な交通問題を, 全 交通機関を考慮して解決するための交通調査研究手法で ある. MMS の手法は, すでに, 1998 年の Road Reviewの中 
表一 ブレア政権登場以降の英国の交通計画システムの整理

\begin{tabular}{|c|c|c|c|c|c|}
\hline \multirow{2}{*}{ 暮理垻目 } & \multirow{2}{*}{ 囁目 } & \multicolumn{2}{|c|}{ 国(中英政麻) } & \multirow{2}{*}{ 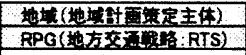 } & \multirow{2}{*}{ 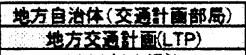 } \\
\hline & & PPG13 & 10) & & \\
\hline 根挻法等 & & な & な & PPG11 & 2000 年交通法 \\
\hline \multirow{5}{*}{ 計面内容 } & 位宣づけ・特做 & 交通計画に関する国の指針 & 中期的指針+具体的予算計画 & $\begin{array}{l}\text { 中長期的な地域の交通部面+ } \\
\text { 地方交通計画人の指金十. }\end{array}$ & $\begin{array}{l}\text { 地方自治体内の交通計面+国 } \\
\text { 力らの交付全に対する入札 } \\
\end{array}$ \\
\hline & 計面目禛の具体性 & 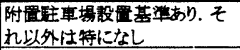 & $\begin{array}{l}\text { かなり真体的なアウトカム指柇 } \\
\text { リスト有り }\end{array}$ & $\begin{array}{l}\text { 特定の具体的目標はない(地 } \\
\text { 域に依存) }\end{array}$ & $\begin{array}{l}\text { 具体的目標設定が竞務. 自治 } \\
\text { 体によって目糧が異なる }\end{array}$ \\
\hline & 目诨年次·期间 & 特になL & 2010 年(10年間) & $15 \sim 20$ 年間 & 5年间 \\
\hline & 上位制的 & 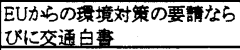 & 主に交通白書 & PPG, 10简年計画，交通白書 & 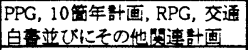 \\
\hline & 下位制約 & $\begin{array}{l}\text { 従わなけれれ圷，地方交通計画 } \\
\text { 入札の予算配分可能性娍 }\end{array}$ & $\begin{array}{l}\text { この計画に沿って，各分野への } \\
\text { 予算配分 }\end{array}$ & \begin{tabular}{|l|} 
現時点ではあまりないが，今後 \\
地方交通計画への制約强化 \\
\end{tabular} & なL \\
\hline \multirow{3}{*}{ 計画手䗷 } & 関係主体间的鳌 & 事前に䛨論 & 不明 & $\begin{array}{l}\text { GO, RDA，HA，SRA等との密 } \\
\text { 接な調整，マルチモーダルスタ } \\
\text { ティとの連舫 }\end{array}$ & 閣俰主体との密接な调整 \\
\hline & 住民数加 & 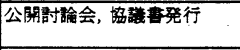 & 不明 & 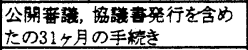 & $\begin{array}{l}\text { 住民考加のやり方, 程度も入札 } \\
\text { における国の嗐価対象 }\end{array}$ \\
\hline & 改訂手䑱 & 適宣改訂 & 必要に志じて改訂 & 必要に応して改写 & 最低5年に一度改壱 \\
\hline \multirow{3}{*}{ 計画評価 } & 䒠前評侐 & 事前に四保主体と議詇 & 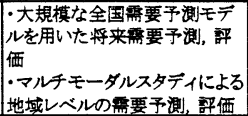 & 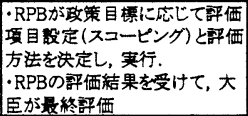 & 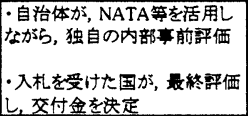 \\
\hline & モニタリング & $\begin{array}{l}\text { 地方自治体でのPPG活用状涚 } \\
\text { を適宜モニタリング }\end{array}$ & 定期的なモニタリソンク & 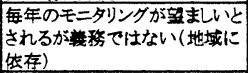 & $\begin{array}{l}\text { 年次報告書の提出，公開の翯 } \\
\text { 務 }\end{array}$ \\
\hline & 透成度評価 & 定期的に適宜評価 & 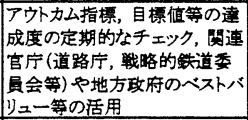 & $\begin{array}{l}\text { 価が望ましいとされるが，特 } \\
\text { 定の方法があるかけでない(地 } \\
\text { 域に㑈存) }\end{array}$ & 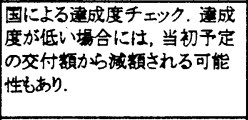 \\
\hline \multirow{4}{*}{ 交通政策との関係 } & 牿合化 & 土地利用との連舫を㚗視 & 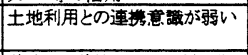 & 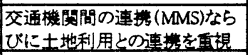 & すこ゚ての連携が直視される \\
\hline & 官民協力 & 通勤交通の㻩境配后 & \begin{tabular}{|l|} 
道路，鉄道等でPPPを積極推 \\
\end{tabular} & RDAとの連萼強化 & バス品留势定，品贸秝約 \\
\hline & 料金政策 & 特になし & 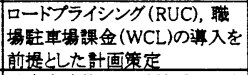 & 特になし & 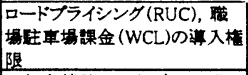 \\
\hline & 地方分梅 & 特になし & $\begin{array}{l}\text { 地方自治体の文通計画への大 } \\
\text { 幅な予算增強 }\end{array}$ & $\begin{array}{l}\text { 地方自治体の連合体(RPB)が } \\
\text { 策定を主望 }\end{array}$ & 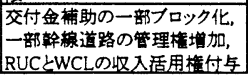 \\
\hline
\end{tabular}

注:各種資料をもとに筆者作成

で $\mathrm{GO}$ とHAによって試行的に実施され, trunk road の整備 計画に反映されていたという経緯がある.これを受けて， 2001 年よりすべての MMS は RPB の責任によって実施され ることとなった. MMS では, 現状把握に始まり, 交通および 土地利用計画, 政策オプションの整理, 交通・土地利用需要 予測モデルの構築, モデルを用いた需要の予測, 環境影響 評価, 費用便益分析を含めた社会経済評価, 計画・政策の 提案, 予算計画, 実行計画の策定等が実施される. MMS の 検討においては, 関係主要機関から構成される Steering Group を中心として, コンサルタント会社の協力の下, 関連 するガイダンス等に基づいて作業が行われる. MMS の検討 結果は, RTS のみならずLTP にも 反映される. また MMS で提案され たプロジェクトについては, 中央政 府から実行予算が配分されることと なっている.

MMS が対象とするのは, 主に各 region の幹線交通軸である. 国レ ベルの問題である都市間交通と地 方自治体レベルの問題である日常 生活交通とをともに考慮することに より, region 間の旅行者の利便性 向上を視野に入れつつ, 地元住民 の日常交通サービス水準も向上さ

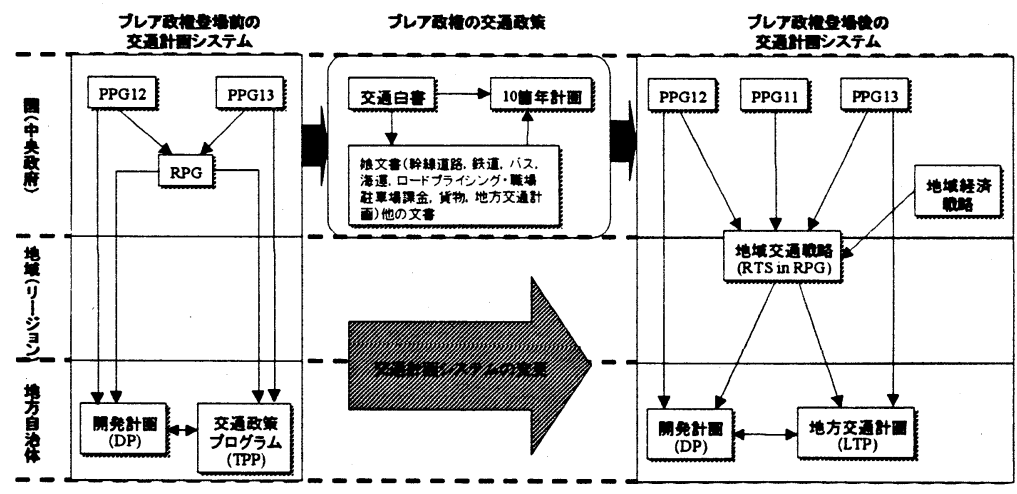

図-6 ブレア政権登場前後の英国の交通計画システムの変化 注:各種资料より等者ら作成 


\section{3 英国の交通計画システムとブレア政権の交通政策との 関係}

以上で示したように, ブレア政権が新たに打ち出した交通 政策は, 交通計画制度のスクラップアンドビルドをもたらした. 計画は, 政策(あるいは理念)を具現化するための一つの実 行手段あるいは目標であり, 計画システムはその政策を効 果的に実現させるための個別計画の組み合わせであるから には, 政策の変化とともに計画システムもある程度, 変更さ れるのは当然のことである.

そこで, 現行の英国の交通計画システムを, 計画内容, 計 画手続, 計画評価ならびにブレア政権の交通政策と関連ゔ けながら, 国, 地域, 地方自治体の3段階で整理したものが 表6である.

また, ブレア政権による交通政策転換の前後における, 英国の交通計画システムの変化を図示したものが, 図6 で ある.これからも, 少なくとも交通計画体系は, region に重点 を置くものになりつつあることがわかる. ただし, ヒヤリングの 結果からもわかるように, その運用に関してはまだ十分に対 応ができていない可能性が高く, 実質的に機能するまでに は, しばらくの時間が必要なものと考えられる.

\section{5. まとめ}

\section{(1)我が国への示唆}

以上で英国における交通政策の変化, ブレア政権の交通 政策と交通計画システムの改変について整理してきた. 以 下に, 英国の事例分析の成果をもとに我が国への示唆をと りまとめる.

まず, 第一に, 英国の交通計画システムはクリアである. 国, 地域, 地方自治体の3つの段階で交通計画を策定する ことが明確に定められており,それらの関係がわかりやすい. 特に, 地域交通戦略(RTS)が, 国と地方自治体の交通計画 の橋渡しをすることで, 各地方自治体の交通計画が広域の 視点から見たときどう位置づけられるか，あるいは中央政府 の定める基本政策が地方自治体の交通計画にどう反映され るのかが明確になっている. そして, 、ルチモーダルスタデ ィ(MMS)の導入等に見られるように, 広域交通計画の役割を さらに強化する方向で, 現在, 交通計画システムの構筑が 進められつつある.ここでは, 広域交通計画により, 人や物 の実際の移動に即した実効性のある計画を策定できること, 国から地方自治体までの計画の一貫性を確保できること，地 方分権を実現するための一ステップとして期待できること等 が強く意識されている.さらに, 交通機関間の連携に配虑し た総合交通計画も強く志向されている.ここでは，交通機関 間の補完あるいは競合の関係を明示的に考慮することによ り，個別交通機関単位の計画が持つ無駄や偏りをなくし，よ り整合的でバランスのとれた計画を策定しようとしている.し たがって, 異なる交通計画間の関係を明確にし, クリアな計
画システムを作ることが我が国でも重要であると思われる.

第二に，英国では，交通計画が土地利用計画から分離さ れ，独立して取り扱われる傾向にある. 例えば, 国レベルで は10箇年計画, 地域レベルでは地域交通戦略, さらに地方 自治体レベルでは地方交通計画のように，それぞれ交通に 特化した計画システムが用意されている. そのため, 交通問 題を明確に抽出し，首尾一貫した議論をしやすい仕組みと なっている. ただし，交通計画と土地利用計画の連携確保 が困難になるといら久点もあり, 英国ではこの問題解消にか なり苦労しているようである. 英国の一部の自治体(例えば, Cambridgeshire County)では, 将来の交通計画を策定する 際，土地利用計画とのセットで複数の代替案を作成し，交通 需要を分析して市民に提示する手法を採用している. 例え ば,こうした，いわゆる交通・土地利用モデルの活用も，今 後の我が国における交通計画策定においても重要視される べき点だと考えられる.

第三に, 英国では, 交通計画システムに関する地方分権 が中央主導で進められている. 害は, 英国では RPG 策定主 体が誰であるべきかが一時論争となつたが, 地域単位の交 通計画案策定主体は RPB とすることを, 中央政府が宣言す ることで事態の収束が図られたといら経緯がある ${ }^{47}$.さらにそ の後 RPBに対する中央政府からの財政的支援も行われた. だが, 「トップダウン式にボトムアップ式の計画システムを確 立する」ということは，それ自体に自己矛盾を含んでいると 考えられる. 一方で, システム変革の過渡期ではできるだけ 速やかに新ンステムの運用方法を決定していく必要があり, ボトムアップ式に意見集約をしていては, 時宜を逸してしま う, という側面もある. 英国の例は, 計画システムの地方分権 を確実かつ早急に進めるためには，地方自治体の主体性と 中央政府のリーダーシップにバランスが要求されることを示 していると思われる.

\section{(2)英国の抱える問題}

前保守党政権は, 交通政策転換の重要性には十分気つ いていた. 実際, 政策転換を図ろうとしていたが, 実効性の ある方策を提示しきれなかった. その意味でブレア政権は， 前政権末期に高まりを見せた環境重視への世論の高まりと 前政権が作った交通政策のアイディアを基本的にそのまま 継承しただけであり，むしろ新たな交通政策が高い実効性 を持つかのように巧みに(スピンドクターを活用して)国民に 示したことが，国民の支持を得た理由なのかもしれない．

実際, 英国の計画システムには，見習うべき点も多いが， かなりの問題を抱えていることも事実である. まず, 英国流 の計画システムは, 基本的な考え方や枠組みのみを中央政 府が提示し, 実際の運営は担当機関に任せるところに1つ の特徵がある. 実際, 英国の政策は, "statement policy"で あるとよく言われるようである.これにより，担当者にある程 度の自由裁量が与えられ, 結果として担当者間あるいは地 
域間に多様性が確保される. 一方で, 英国では, "Good policy, bad practice"といら䜓があるという.この意味すると ころは, 政策の概念の整理は英国人の得意とするところだ が, 運営, 実行がそれに伴わないことがしばしばあるという ことのようである. また, 英国では, 国レベルから地方自治体 レベルに至るまで交通あるいは土地利用に関するさまざま な計画, ガイダンス等が存在し, 相当に複雑な仕組みとなつ ているが, そのカバーする範囲がしばしば不明確なことが 多い.このような緩やかな計画システムは, 各計画における 策定主体の自由度を大きくするという刚怆ある反面, 既 成の権限構造が巧みに保持され実質的に計画策定の自由 度を小さくしている可能性もある. 同様に, 各種地方分権的 な計画システムが用意される一方で, 相変わらず予算配分 権限が国に集中している点や地方自治体の監視, 監查に関 して国(担当大臣)の介入する余地を認めている点等におい て, 実質的に中央集権的な仕組みを維持している点にも, やや矛盾があるように思われる. ただし,これらの問題に関 しては, 現在計画システムの転換期だからやむを得ないと の意見もありうるが, 英国の抱えている本質的, 構造的な欠 陥であるとも考えられる。

\section{(3)おわりに}

国土計画の視点から見れば, 英国の交通計画体系は， regionを中心とした計画に変わりつつある. これは, EU の地 域を優先する考え方とも一致しており，今後はさらに地域議 会の設立等によってこの流れは加速するものと予想される. 無論, こうした諸外国の流れをそのまま我が国で柌吞みに する必要は, 必ずしもない. 他国の方法を単純輸入するだ けでは, 我が国の実情に即した計画システムを構筑できな いことは当然である. しかし, 我が国の国土計画体系のあり 方を模索する際，他国の教訓十分に参考にしながら，明 確な国土ビジョンとそれに向けた真に効果的な方法論を， 丁寧に議論していく姿勢こそが, 今後の計画システムを構 築していく上で, 必要不可欠であると考える. その意味で今 後とも英国の交通計画体系の動向は注目に值すると考えら れる.

\section{【付録:主要略語表】}

\begin{tabular}{|l|l|l|}
\hline 略語 & 正式名标 & 日本語名称 \\
\hline DETR & Department of Environment, & 環境交通地域省 \\
& Transport and the Regions & \\
DP & Development Plan & デベロップメントプラン \\
DTI & Department of Trade and Industry & 通商産業省 \\
GLA & Greater London Authority & 大ロンドン庁 \\
GO & Govemment Office for the Regions & 中央政府の地域出先機関 \\
HA & Highways Agency & 道路庁 \\
LTP & Local Transport Plan & 地方交通計画 \\
MMSs & Multimodal Studies & マルチモーダルスタディ \\
MPG & Mineral Planning Guidance & 採掘計画カイダンス \\
NATA & New Approach to Appraisal & 新たな評価アプローチ \\
\hline
\end{tabular}

\begin{tabular}{|c|c|c|}
\hline ORR & Office of the Rail Regulator & 鉄道規制局 \\
\hline PPG & Planning and Policy Guidance & 計画政策方針ガイダンス \\
\hline $\mathrm{RDA}$ & Regional Development Agency & 地域開発庁 \\
\hline RPB & Regional Planning Body & 地域計画機粠 \\
\hline RPG & Regional Planning Guidance & 地域計画ガイダンス \\
\hline RTS & Regional Transport Strategy & 地域交通戦格 \\
\hline RUC & Road User Charging & ロードプライシング \\
\hline SRA & Strategic Rail Authority & 戦略鉄道委員会 \\
\hline TPP & Transport Policies and Programme & 交通政策プログラム \\
\hline TSG & Transport Supplementary Grant & 交通槌加交付金 \\
\hline WPL & Workplace Parking Levy & 職場駐車場課金 \\
\hline
\end{tabular}

\section{【綝辞】}

本研究を進めるに当たり，多の方々にサポートをしていただいた. まず， 友成真一氏(元国土交通省国土計画局), 望月拓郎氏(国土交通省国土計画 局)，森毅彦氏 (元在連合王国日本国大使館), 五十木和世氏 (One NorthEast 東京事務所), 堤盛人諢師(Durham University)には, インタビュー あるいはその準備でお世話になった. また, The University of Manchesterの Michael Hebbert 教授, DTLR の Phil Alker 氏, Guy Denman 氏, lan Holmes 氏, DTI $の$ Nigel Dotchin 氏, Highway Agency $の$ Keith R Shaw 氏, Greater London Authority の Giles Dolphin 氏ならびにStewart Murray 氏, Government Office for London $の$ Anthony Thompson 氏, Government Office for the North West $の$ Stephen Truswell 氏, North West Regional Assembly の Tim Hill 氏, Northwest Development Agency $の$ Helen France 氏, Greater Manchester Passenger Transport Authority $の$ Richard Elliott 氏, SouthEast Regional Assembly $の$ Mike Gwilliam 氏, One NorthEast $の$ Michelle Lowes 氏, Trevor Higgs 氏, Mark Henderson 氏, South East England Development Agency Pat Tempany 氏, Geoff Hawkins 氏, Detlef H Gollets 氏, Durham County CouncilのRoger Elphick OBE氏らにはインダ゙ューにおいてご協力をいただ いた.なお, イン多ュ゙ーは, 2001 年秋から 2002 年にか忛て行われた. また, 本研究の成果の一部は, 平成 13 年度諸外国における国土計画制度等の分 析調查(国土交通省国土計画局)およひ社会技術研究システム・シッションプ ログラムの研究成果によるものである. 関係する方々のご協力に深く感謝の 意を表したい.

\section{【参考文献】}

1) Department of Environment, Transport and the Regions (1999) Transport Trends, The Stationery Office.

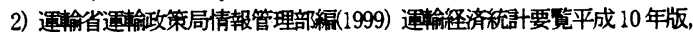
(財)運輸政策研究機粠.

3) Department of Environment, Transport and the Regions (2000) Transport 2010: The 10 Year Plan

4）運輸政策番議会(2000) 長期腀送需要の予測, 運輸政策番諈会答申第 20 号, 総合部会長期輸送需要予測小委員会報告。

5) Commission for Integrated Transport (2002) Public Attitudes to Transport in England, MORI.

6) Truelove, P. (2002) Transport Planning, in British Planning. 50 years of Urban and Regional Policy, (ed .) Cullingwoth, B., pp.198-212.

7) Ministry of Transport[1963] Traffic in Towns The Buchanan and Crowther Reports), H.M.S.O. (全訳が, 八十岛義之助・井上 孝[1965]「都市の自動 車交通，鹿島出版会にある. )

8）舟場正富(1998) ブレアのイギリス一福祉のニニーディールと新産業主義 一, PHP 新書 056

9) Labour Party (199i) Labour Party Election Manifesto.

10) Department of the Environment, Transport and the Regions[1998a] $A \mathrm{New}$ Deal for Transport : Better for Everyone.

11) Department of Environment, Transport and the Regions (1998) $A$ New Deal for Trunk Roads in England.

12) Department of Environment, Transport and the Regions (1999) From Workhorse to Thoroughbred: A Better Role for Bus Travel.

13) Department of Environment, Transport and the Regions (1999) A New Deal for the Ralways.

14) Department of Environment, Transport and the Regions (1999) Sustainable Distribution: A Strategy.

15) Department of Environment, Transport and the Regions (1999) Green Transport Plan - The Benefits of Green Transport Plans: The Guide. 
16) Department of Environment, Transport and the Regions (1999) Guidance on Aipport Transport Forums and Airport Sunface Access Strategies.

17) House of Commons (1999) Transport Bills および Department for Transport (2001) Transport Act 2000 - Regulatory Impact Assessment.

18) Department of Environment, Transport and the Regions (2000) Transport 2010: The 10 Year Plan.

19) Hine, J. (2000) Integration, integration, integration ... Planning for sustainable and integrated transport systems in the new millennium, Transport Policy, Vol.7, No.3, pp.175-178.

20) Vigar, G. (2001) Implementing transport's 'new realism'?: The dissemination of demand-management policies in UK transport planning, Town Planning Review, Vol.72, No.4, pp.423-443.

21) Department of Environment, Transport and the Regions (1998) Guidance on the New Approach to Appraisal.

22）山中英生(1997) イギリスにおけるパッケージ・アプローチと公共交通ウエスト・シッドランド LRT 整備にみるその課題一, 運輸と経済, 第 57 号, 第6号, pp.55-65.

23）運輸政策審議会自動車交通部会(1999）乗合バスの活性化と発展を目指 して〜乗合バスの需給調整規制廃止に向けて必要となる環境整備方策等 について〜.

24）寺田一薰(2002) バス産業の規制緩和, 日本評論社

25) Department for Transport (2002) Directions and Guidance to the Strategic Rail Authority.

26) Department for Transport (2002) Statutory Guidance to the Rail Regulator.

27）富永憲治(2001)「イギリスにおける鉄道改革と 2000 年交通法」，運鍮と経 済, 第 61 巻第 10 号, pp.30-41.

28) Department of Environment, Transport and the Regions (1998) Breaking the Logjam The Government's consultation paper on fighting traffic congestion and pollution through road user and workplace parking charges.

29）加藤浩徳，山内弘隆(1999) ロンドンへのロードプライシング導入に関す る関倸主体間の議論, 運輸政策研究Vol.2, No.2, pp.32-41.

30）財務省財務総合政策研究所 (2001) 主要国の地方税財政制度 (イギリス・ ドイツ・フランス・アメリカ).

31）財務省財務総合政策研究所(2002）地方財政システムの国除比較.

32) Department of the Environment, Transport and the Regions (2001) Strengthen Regional Accountability-Consultation Paper.

33) Department of Environment, Transport and the Regions (1999) Planning Policy Guidance Note 13: Transport

34）谷口 守(1998) 土地利用·交通計画一体化のためのガイドラインの実際 と課題ーイングランドの PPG13 からー, 土木計画学研究·論文集, No.15, pp.227-234.

35) Department of the Environment, Transport and the Regions (1999) Guidance on the Methodology for Multi-Modal Studies, Vol.1, Vol.2.

36）中野宏幸(1999）英国の地域交通行政と今後における地域交通アプロー チのあり方, ITPS Report 9902, 運輸政策研究所.

37) Department of Environment, Transport and the Regions (1999) Guidance on
Full Local Transport Plans.

38）加藤浩徳·堀 健一・中野宏幸(2000）英国における地方レベルの新たな 交通計画システム-Local Transport Plan の導入と実態-, 運輸政策研 究Vol.3, No.2,pp.21-30.

39）加藤浩徳(2001）英国における地方レベルの交通計画に関する予算シス テム, 都市計画, Vol.50, No.2, pp.29-32.

40) Cabinet Office (2000) Reaching Out: The Role of Central Govemment at Regional and Local Level, A Performance and Innovation Unit Report.

41) Highways Agency (1999) Framework Document.

42) Highways Agency (2001) Business Plan 2001/02 - Delivering the 10 Year Plan.

43) Department of Trade and Industry (1999) Regional Development Agencies General Information.

44) Department of Trade and Industry (1999) Regional Development Agencies Regional Strategies.

45) Department for Transport, Local Government and the Regions (2001) Regional Chambers.

46) Department of Environment, Transport and the Regions (1999) Planning Policy Guidance Note 11: Regional Planning

47) Cullingwoth, B. and Nadin, V. (2002) Town \& County Planning in the UK, 13th edition, Routledge, London.

48) Jones, P. and Lucas, K. (2000) Integrating transport into 'joined-up' policy appraisal, Transport Policy, Vol.7, pp.185-193.

49) Department of the Environment, Transport and the Regions (2000) Regional Government in England - A Preliminary Review of Literature and Research Findings.

50) Owens, S. (1995) From 'predict and provide' to 'predict and prevent'? ppricing and planning in transport policy, Transport Policy, Vol.2, No.1, pp.43-49.

51) Bonsall, P. (2000) Legislating for modal shift: background to the UK's new transport act, Transport Policy, Vol.7, pp.179-184

52) Caims, S. (2000) The Importance of the multi-modal studies, Town \& County Planning, July/August, pp.210-211.

53) Pattison, G. (2001) Regionalism or centralization?, Town \& County Planning, January, p.21.

54) Weaver, N. (2001) Implementing the principles of the Transport White Paper the challenge, Town \& County Planning, May, pp.146-147.

55）国土交通省国土計画局(2001) 平成 13 年度諸外国における国土計画制 度等の分析調查報告書.

56）国土宁(1998)21 世紀の国土のグランドデザインー地域の自立の促進と 美しい国土の創造.

57）国土番㦈会政策部会, 土地政策譒議会計画部会(2000) 21 世紀の国土計 画のあり方ー21 世紀の新たな要請にこたえ得る国十計画体系の確立を目

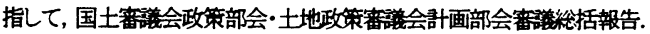

58）中井検裕・村木美贵(1998) 英国都市計画とマスタープラン一合意に基 ぶ政策の奏現プログラムー, 学芸出版会.

\section{英国の新たな交通計画体系權策に向けた新みとその我が国への示唆}

加藤 浩徳, 村木 美貴, 高橋 清

本稿は，近年の英国の交通政策とそれに伴う交通システムの変化を調查し，整理することを目的とするものである. 英国で は, 1997 年のブレア政権成立以来, 新たな交通政策が実施されてきた。新交通政策の特徴は、「総合化」「官民協力·調 整」「経済的交通需要マネジメン」,「地方分権しいいった点に見られる。 またその結果, 交通計画に関わる国, 地方自治体、 地域の役割が変化し，交通システム全体にも変更がもたらされた. 特に, 前政権の規制緩和政策への反動之地方分権が大 きな影響を及ほてていると考えられるが, 英国内にも実効性が伴わないとの批判も強く, 今後の推移が注目される。

\section{Recent Transport Planning System in England and Its Lessons to Japan}

By Hironori KATO, Miki MURAKI and Kiyoshi TAKAHASHI

This paper aims to review the transport planning system in England and to discuss its implication to Japan. Recently many new transport policies have been introduced into England since the New Labor Party headed by Prime Minister Blair started in 1997. For instance, the transport planning in regions is one of the most important issues in the new transport policy, because the regionalism is a key trend in terms of decentralization of the United Kingdom. We review the present England's transport planning system and analyze their strong and weak points. Then, we discuss how Japan's transport system should be in the context of revision of the national plannins system. 